\title{
Serum pepsinogen I concentrations in peptic ulcer patients in relation to ulcer location and stage
}

\author{
Y Tanaka, K Mine, Y Nakai, N Mishima, T Nakagawa
}

\begin{abstract}
To investigate the relation of the serum group I pepsinogen (PG I) concentration to the location of gastric ulcers and chronicity of peptic ulcers, ulcer patients $(n=322)$ were compared with endoscopically normal subjects $(n=174)$. The mean PG I concentration was significantly higher in male control subjects $(n=90)$ than in female control subjects $(n=84)$. In male patients with ulcers in the duodenum $(n=69)$, antrum $(n=34)$, or angulus portion (the lower third of the body; $n=83$ ), the mean serum PG I concentration was significantly higher than in the control subjects but in patients with an ulcer in the upper body $(n=49)$ it was similar to control values. Men with active or healing ulcers $(n=149)$ showed a significantly higher serum PG I concentration than those with scarred lesions $(n=86)$ when the abnormality was located in either the upper body or in the angulus portion. For female patients $(n=87)$, the results were similar. These results suggest that serum PG I concentrations reflect the stages of activity of peptic ulcer.
\end{abstract}

It has been reported that hyperpepsinogenaemia may be considered as a subclinical marker of the genetic predisposition to duodenal ulcers. ${ }^{1-4} \mathrm{It}$ has been fairly well established that duodenal ulcer patients often show increased serum concentrations of group I pepsinogen (PG I $)^{5-11}$

Several studies have found a significant relation between the serum PG I concentration and gastric acid and pepsin output in response to maximal stimulation with histamine or pentagastrin, suggesting that the serum PG I concentration may reflect the acid and pepsin secretory capacity of the gastric mucosa. ${ }^{112}$

With regard to gastric ulcers, however, the importance of the serum PG I concentration has not yet been established and there is still no unified view on the subject. ${ }^{5-11}$ There have been few reports of serum PG I concentratons in relation to the location of gastric ulcers, ${ }^{8-10}$ nor has the relation of serum pepsinogen or PG I to the stage of activity of peptic ulcers been investigated often..$^{1013}$

This study was undertaken to further a better understanding of the relation between serum PG I and peptic ulcers. Peptic ulcer patients were compared with endoscopically normal control subjects with regard to serum PG I concentrations. In particular, we investigated whether there was any relation between the location or the stage of the ulcer and the serum PG I concentration. All subjects were socioculturally relatively homogeneous inhabitants of an isolated island.
Subjects and methods

SUBJECTS

All subjects were from Iki island, Japan. Iki is an isolated island with a population of about 40000 and is $139 \mathrm{~km}^{2}$ in area. Almost all residents are engaged in either fishing or agriculture and have similar customs and environment. Migration from or to the island is rare.

We examined all subjects by endoscopy in Iki Public Hospital over a seven year period from 1980 to 1986. Almost all endoscopic examinations of the patients from Iki island were performed at this hospital. We used an Olympus GIF Q endoscope. In all patients with gastric ulcer biopsy specimens were taken, none of which showed malignancy.

The control group consisted of healthy volunteers and outpatients who were suspected of having gastric or duodenal disease after mass cancer $x$ ray screening, as well as those who had a negative history of peptic ulcers and in whom no gastric or duodenal abnormalities could be observed by endoscopy. All healthy volunteers were informed of the study by letter and gave their written consent.

Patients with gastrointestinal symptoms not attributable to peptic ulcers were also included, but none of the control subjects had any severe underlying diseases.

The peptic ulcer group consisted of patients with a single gastric or duodenal ulcer that was shown to be active, healing, or in the scarred stage at endoscopy. Patients with multiple ulcers and those in whom the ulceration was considered to be induced or affected by taking anti-inflammatory agents such as aspirin or indomethacin were excluded. All ulcer patients were treated with antacid and sucralfate, combined with firm persuasion to better their eating habits and life style. No patient receiving either anticholinergic agents or $\mathrm{H}_{2}$ blockers was included in the patient group.

There were 174 subjects in the control group 90 men and 84 women with a mean (SD) age of 48 (14) years. The peptic ulcer group consisted of 322 patients. Some 217 had a gastric ulcer - 166 men and 51 women, with a mean (SD) age of 54

TABLE I Mean (SD) serum pepsinogen I (PG I) concentration in subjects according to age and sex

\begin{tabular}{|c|c|c|c|c|c|}
\hline \multirow[b]{2}{*}{ Age (yrs) } & \multicolumn{2}{|c|}{ Men } & \multicolumn{2}{|c|}{ Women } & \multirow{2}{*}{$\begin{array}{l}\text { Comparison } \\
\text { men v women }\end{array}$} \\
\hline & No & $P G I(n g / m l)$ & No & $P G I(n g / m l)$ & \\
\hline $\begin{array}{l}20-29 \\
30-39 \\
40-49 \\
50-59 \\
60-69 \\
70-78 \\
\text { Total }\end{array}$ & $\begin{array}{r}5 \\
23 \\
19 \\
19 \\
18 \\
5 \\
90\end{array}$ & $\begin{array}{l}87 \cdot 8(18 \cdot 5) \\
77 \cdot 7(26 \cdot 4) \\
66 \cdot 0(22 \cdot 2) \\
71 \cdot 7(23 \cdot 8) \\
82 \cdot 0(26 \cdot 7) \\
76 \cdot 0(32 \cdot 3) \\
75 \cdot 3(25 \cdot 0)\end{array}$ & $\begin{array}{l}10 \\
22 \\
10 \\
16 \\
19 \\
7 \\
84\end{array}$ & $\begin{array}{l}64 \cdot 3(21 \cdot 8) \\
63 \cdot 6(25 \cdot 7) \\
69 \cdot 8(33 \cdot 3) \\
73 \cdot 1(23 \cdot 1) \\
65 \cdot 4(19 \cdot 1) \\
67 \cdot 0(9 \cdot 7) \\
66 \cdot 9(23 \cdot 1)\end{array}$ & $\begin{array}{l}\text { NS } \\
\text { NS } \\
\text { NS } \\
\text { NS } \\
p<0.05 \\
N S \\
p<0.05\end{array}$ \\
\hline
\end{tabular}


(13) years - and 105 had a duodenal ulcer - 69 men and 36 women with a mean (SD) age of 48 (12) years.

MEASUREMENT OF SERUM PG I CONCENTRATIONS On the day of endoscopy, blood samples from all subjects were collected in glass tubes early in the morning after an overnight fast. After centrifugation the serum was stored at $-20^{\circ} \mathrm{C}$ until assays were performed. The concentration of PG I was determined by radioimmunoassay according to Samloff's method, ${ }^{14}$ using a PG I RIA kit (Midori Juji). For all the samples, duplicate measurements were performed.

With regard to the control group, we examined the distribution of serum PG I concentrations according to age and sex.

The 322 peptic ulcer patients were classified into four groups according to the location of the ulcer. These locations were: the duodenal bulb; the antrum distal to the angulus; the distal third of the corpus including the angulus, referred to in this text as the 'angulus portion'); and the proximal two thirds of the corpus, referred to as 'upper corpus'.

In addition, for each location we compared the patients with an ulcer in the active or healing stage, referred to as an 'open ulcer' with patients with an ulcer in the scarred stage according to Sakita's classification. ${ }^{15} 16$

\section{STATISTICS}

The results are expressed as mean (SD). The statistical significance of the different distributions of serum PG I concentrations in the various groups was determined by means of Student's $t$ test and the analysis of variance (ANOVA).

\section{Results}

CONTROL GROUP

Comparing the different age groups among control subjects showed no significant differences in the mean serum PG I concentration. This result can be attributed to the small number of subjects in each age group. The PG I concentration was significantly higher, however, in men than in women (Table I). The control group subjects has a mean (SD) serum PG I concentration of $71 \cdot 2(24 \cdot 4) \mathrm{ng} / \mathrm{ml}$.

\section{PEPTIC ULCER GROUP}

Because there were statistically significant differ-

TABLE II Mean $(S D)$ serum pepsinogen I (PG I) concentration in male ulcer patients according to location and stage of ulcer

\begin{tabular}{|c|c|c|c|c|c|}
\hline \multirow[b]{2}{*}{ Location } & \multicolumn{2}{|c|}{ Open ulcer } & \multicolumn{2}{|c|}{ Ulcer scar } & \multirow{2}{*}{$\begin{array}{l}\text { Comparison } \\
\text { open v scar }\end{array}$} \\
\hline & No & $P G I(n g / m l)$ & No & $P G I(n g / m l)$ & \\
\hline $\begin{array}{l}\text { Gastric ulcer: } \\
\text { Upper corpus } \\
\text { Angulus portion } \\
\text { Antrum } \\
\text { Duodenal ulcer } \\
\text { Control }\end{array}$ & $\begin{array}{r}106 \\
35 \\
43 \\
28 \\
43\end{array}$ & $\begin{array}{l}130 \cdot 7(58 \cdot 3)^{\star} \\
86 \cdot 5(35 \cdot 3) \\
157 \cdot 7(56 \cdot 2)^{\star} \dagger \\
144 \cdot 3(53 \cdot 4)^{\star} \dagger \\
145 \cdot 2(51 \cdot 8)^{\star} \dagger \\
n=90 \text { serum I }\end{array}$ & $\begin{array}{r}60 \\
14 \\
40 \\
6 \\
26 \\
5 \cdot 3\end{array}$ & $\begin{array}{l}92 \cdot 2(34 \cdot 4)^{\star} \mathrm{S} \\
64 \cdot 4(21 \cdot 8) \\
96 \cdot 5(30 \cdot 3)^{\star} \ddagger \\
128 \cdot 0(41 \cdot 0)^{\star} \dagger \\
124 \cdot 2(51 \cdot 5)^{\star} \dagger \\
9(\mathrm{ng} / \mathrm{ml})\end{array}$ & $\begin{array}{l}\mathrm{p}<0.0001 \\
\mathrm{p}<0.01 \\
\mathrm{p}<0.0001 \\
\text { NS } \\
\text { NS }\end{array}$ \\
\hline
\end{tabular}

${ }^{\star} p<0.01$ compared with the control group. $t p<0.01$ compared with the patients with an ulcer in the upper corpus. $\neq \mathrm{p}<0.05$ compared with the patients with an ulcer in the upper corpus. $\$ p<0.01$ compared with the patients with duodenal ulcer. ences between the men and women in the control group, we investigated the male and female ulcer patients separately. The ulcer patients were divided into those with open (active or healing) ulcer lesions and those with an ulcer scar.

\section{COMPARISON BETWEEN PATIENTS AND CONTROL} SUBJECTS

Male patients with ulcers in the angulus portion, the antrum, or the duodenum, either active or healing as well as in the scarred stage, had appreciably higher serum PG I concentrations than the control group (Table II).

The patients with an open ulcer or a scar in the upper corpus, however, showed no significant difference in serum PG I concentrations compared with the control subjects. With regard to ulcer location, the serum PG I concentration was significantly lower in patients with ulcers in the upper corpus than in those with ulcers in other locations, both for men with an open ulcer and for those with an ulcer scar.

The results in female ulcer patients were similar to those in male patients, except that there were too few women with a scar in the antrum to determine any statistical significance when comparing the difference in serum PG I concentrations (Table III). Although PG I concentrations tended to be higher among female patients with a scar in the angulus portion compared with those with a scar in the upper corpus, there was no statistically significant difference between these locations.

\section{COMPARISON BETWEEN PATIENTS WITH AN OPEN}

\section{ULCER AND A SCAR}

Men with a gastric ulcer that was active or healing had noticeably higher serum PG I concentrations than those with scarring. In patients with an ulcer in the upper corpus or angulus portion, the serum PG I concentration was significantly higher in those with an open ulcer than in those with a scar. In patients with an ulcer in the antrum or duodenum, the PG I concentration also seemed to be higher in active or healing lesions than in scarred ulcers. This difference was not, however, statistically significant (Table II).

Female patients with an active or healing gastric ulcer also showed a significantly increased concentration of serum PG I compared with those with an ulcer scar. In ulcers located in the angulus portion in particular, the serum PG I concentrations of patients with an open ulcer seemed to be significantly higher than in those with scarring (Table III).

\section{Discussion}

In this study, all those investigated lived in a similar environment, had similar eating habits and life style, and were of the same race. For a study on peptic ulcers, which is considered to have a multifactorial aetiology, this group of subjects can be regarded as very suitable.

The mean serum PG I concentration of the control group in this study corresponds well with 
TABLE III Mean $(S D)$ serum pepsinogen I (PG I) concentration in female ulcer patients according to location and stage of ulcer

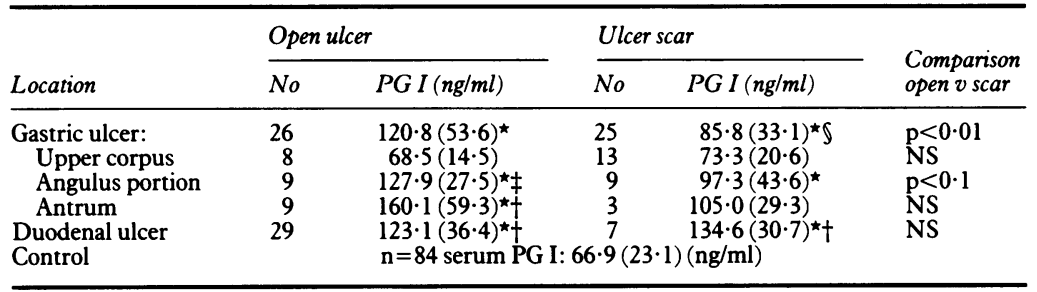

${ }^{\star} \mathrm{p}<0.01$ compared with the control group. $\mathrm{tp}<0.01$ compared with the patients with an ulcer in the upper corpus. $\neq \mathrm{p}<0.05$ compared with the patients with an ulcer in the upper corpus. $\$ \mathrm{p}<0.01$ compared with the patients with duodenal ulcer.

Samloff's results using an improved radioimmunoassay. ${ }^{14}$

The fact that the serum PG I concentration was significantly higher in men than in women is in keeping with previous reports. ${ }^{911718}$ Our finding of a significantly higher serum PG I concentration in duodenal ulcer patients compared with control subjects also agrees with previous reports. ${ }^{5-11}$

With regard to gastric ulcers, Samloff et al, Vianello et al, and Nakanome et al reported that these patients generally showed a higher mean serum PG I concentration than control subjects. ${ }^{5-7}$ In other studies, Samloff et al and Peyre et al reported that patients with an ulcer located in the antrum distal to the angulus showed a higher mean serum PG I concentration than control subjects, but the concentration in patients with an ulcer located at or proximal to the angulus did not differ significantly from that in control subjects. ${ }^{89}$ Plebani et al found that the serum PG I concentration was significantly higher in patients with ulcers located in the angulus or antrum than in those with ulcers proximal to the angulus but did not mention whether there was any statistically significant difference between patients with an ulcer proximal to the angulus and the control subjects. ${ }^{10}$ Previous reports, therefore, show variable results concerning gastric ulcers, especially with regard to those either at or proximal to the angulus.

This lack of consistency may partly be explained by the fact that in previous studies the gastric ulcer patients were divided into only two groups according to ulcer location. In some studies ulcers in the angulus were grouped with antral ulcers while in others they were grouped ulcers in the corpus.

In this study, we were more precise about gastric ulcer locations, investigating the angulus portion separately from the upper two thirds of the corpus. We found significantly higher PGI concentrations not only in patients with antral ulcers but also in those with ulcers localised in the angulus portion, whereas PGI concentrations in patients with an ulcer in the upper corpus were similar to those in control subjects. Oi et al delineated the border zone separating the fundic mucosa from the antral mucosa. They indicted that all gastric ulcerations occurred in the region of the antral gland and that most of the ulcerations were adjacent to the border zone in resected specimens with gastric or duodenal ulcers. ${ }^{19}$ They also reported that distances between the mucosal border and pyloric rings were variable, ranging over a wide area on the lesser curvature..$^{20}$
From information obtained from multiple biopsy specimens in 570 Japanese patients, the fundic-pyloric border was found to transit proximally with advancing age and a proximal transition occurs extending more rapidly along the lesser curvature of the stomach. In addition, atrophic gastritis was also found to expand proximally, extending more rapidly in the lesser than in the greater curvature. ${ }^{21}$

The study also suggested that the fundic gland along the fundal side of the fundic-pyloric border undergoes metaplastic changes into the pyloric gland, resulting in expansion of the area covered by the pyloric glands in accordance with expanding atrophic gastritis. From the results of these studies, it may be presumed that the more proximally ulcers are located in the stomach, the smaller the area that covers the fundic mucosa. These investigations may explain the differences in serum PG I concentrations in relation to the location of ulcers by virtue of the fact that PG $I$ is synthesised only in the fundic gland mucosa. ${ }^{22}$

It has been suggested that the serum PG I concentration may reflect the acid secreting potential. ${ }^{9112}$ It has been shown that, in general, patients with an ulcer in the corpus tend to have either a normal or lower than normal rate of acid secretion, whereas in patients with an antral ulcer the acid secretion is either normal or greater than normal. ${ }^{23-25}$ The different serum PG I concentrations that we observed at three different locations of gastric ulcers, correlate roughly with these different rates of acid secretion. If we assume, however, that the PG I concentration is an index of acid secretory capacity, many patients with an ulcer in the lower third of the corpus (angulus portion) could be presumed to have a relatively high acid secretion.

Our finding of a statistically significant difference in serum PG I concentrations according to the stage of activity of the ulcer has seldom been reported. ${ }^{7}$ In our gastric ulcer patients, both male and female, the serum PG I concentrations in those with active or healing ulcers were significantly higher than in those with scarred ulcers. In men with ulcers located in the upper corpus and in the angulus portion, a significantly higher serum PG I concentration was found in those with open ulcers than in those with scars.

The reason for this difference in serum PG I in open versus scarred ulcers in the upper corpus and angulus portion is not clear. If the serum PG I concentration represents the chief cell mass $^{19111222}$ it is possible that it rises as a result of the destruction of chief cells due to accompanied inflammation in the fundic gland area. It has been reported that the serum PG I concentration in the superficial gastritis group was significantly higher than that in the normal group. ${ }^{26}$

Samloff $e t$ al showed that serum pepsinogen II (PG II) is produced by the chief cells in fundic glands and by the pyloric glands in the gastric antrum, and that raised serum PG II value and a low PG I:PG II ratio are major risk factors for gastric ulcers. ${ }^{27}$ To elucidate the cause of the difference in serum PG I concentrations during the clinical course of gastric ulcer, especially in the antrum, we should investigate serum PG II concentration in further studies.

Another possible mechanism for the dif- 
ference in serum PG I in open versus scarred gastric ulcers is a change in the parasympathetic activity. The serum PG I concentration in duodenal ulcer patients decreases significantly when atropine is administered. ${ }^{7}$ It has been shown in organ culture that the gastric secretion of pepsinogen is stimulated considerably by acetylcholine.$^{28}$ Furthermore, there have been many reports on the significant reduction in serum PG I concentrations after a proximal gastric vagotomy has been performed in duodenal ulcer patients. ${ }^{29-32}$ Based on these findings it might be postulated that the serum PG I concentration is an expression of the function of the parasympathetic nervous system, and that in the active stage of peptic ulcers the function of the parasympathetic nervous system is at a higher level, resulting in an increased concentration of PG $I$ in serum through the increased neural stimulation of the chief cells.

In duodenal ulcer patients, it has already been shown that increased serum concentrations of PG I at the time of diagnosis are associated with a significant tendency to ulcer relapse..$^{71033}$ In gastric ulcer patients, the clinical significance of measuring the serum PG I concentration is not yet clear. We found a difference in serum PG I concentrations in patients with an open ulcer compared with those with a scar, not only for the antrum and the angulus portion but also for the upper corpus. If the serum PG I concentration reflects the acid secretory potential, it could be presumed that the increase in acid and pepsin secretion might play an important role in the onset and recurrence of gastric ulcers, regardless of their location.

It is, however, difficult to elucidate clearly the relation between gastric secretion and ulcer activity from our results. Contrary to the reports showing that serum PG I concentration and the acid and pepsin secretory capacity of the gastric mucosa correlate closely with each other, Feldman et $a l^{18}$ and other authors ${ }^{1034}$ reported that though maximal acid secretion correlated significantly with serum PG I, the correlations were not strong.

Serum PG I concentrations might be considered useful as parameters of ulcer activity in following the clinical course of gastric ulcer patients. Because our findings are based on a cross-sectional study, it is difficult to determine whether serum PG I concentrations increase in the active stage in patients with gastric ulcer or not. In future investigations, longitudinal study of the same patients during the clinical course is required to confirm the clinical importance of serum PG I concentrations.

Since we found statistically significant differences according to sex, the three gastric ulcer sites, and the stages of the ulcer, we recommend that future studies of serum PG I should consider all these aspects.

We are grateful to Dr Ronald Schlemper for critical review, Dr B Quinn for proofreading, Mrs U Taguchi for technical assistance, and to Mrs Y Takeda for her skillful typing.

1 Rotter JI, Sones JQ, Samloff IM, et al. Duodenal ulcer disease associated with elevated serum pepsinogen I, an inherited autosomal 63 .

2 Rotter JI, Petersen G, Samloff IM, et al. Genetic heterogeneity of hyperpepsinogenemic I and normopepsinogenemic duodenal ulcer disease. Ann Intern Med 1979; 91: 372-7.

3 Habibullah CM, Mujahid Ali M, Ishaq M, Prasad R, Pratab B,
Saleem Y. Study of duodenal ulcer disease in 100 families using total serum pepsinogen as a genetic marker. Gut 1984 25: $1380-3$.

4 Taylor IL, Calam J, Rotter JI, et al. Family studies of hypergastrinemic, hyperpepsinogenemic I duodenal ulcer. Ann Intern Med 1981; 95: 421-5.

5 Samloff IM, Stemmermann GN, Heilbrun LK, Nomura A Elevated serum pepsinogen I and II levels differ as risk factors for duodenal ulcer and gastric ulcer. Gastroenterology 1986; 90: 570-6.

6 Vianello F, Plebani M, Piccoli A, et al. Role of serum pepsinogen in detecting ulcer disease. Clin Chim Acta 1988; 172: $335-40$.

7 Nakanome C, Yamazaki H, Tanno N, et al. Serum group I pepsinogen (PG I) levels and their changes in the healing process of the ulcer in patients with and without unoperate recurrent ulcer. Tohoku $\mathcal{F}$ Exp Med 1984; 143: 239-48.

8 Peyre S, Di Napoli A, Pelissero A, Sategna-Guidetti C. Diagnostic usefulness of serum group I pepsinogen deter-
mination. Gastroenterol Clin Biol 1983; 7: 793-8.

9 Samloff IM, Liebman WM, Panitch NM. Serum group pepsinogens by radioimmunoassay in control subjects and pepsinogens by radioimmunoassay in control subjects and
patients with peptic ulcer. Gastroenterology 1975; 69: 83-90

10 Plebani M, Di Mario F, Vianello F, et al. Actual role of pepsinogen group I in the study of upper gastrointestinal diseases. Clin Biochem 1983; 16: 310-2.

11 Nakanome C, Akai H, Goto Y. Serum group I pepsinogen levels in patients with peptic ulcer and normal subjects. Tohoku F Exp Med 1983; 139: 151-8.

12 Samloff IM, Secrist DM, Passaro E. A study of the relationship between serum group I pepsinogen levels and gastric acid secretion. Gastroenterology 1975; 69: 1196-1200.

13 Mirsky IA, Futterman P, Kaplan S. Blood plasma pepsinogen the activity of the plasma from 'normal' subjects, patients the activity of the plasma from 'normal' subjects, patients
with duodenal ulcer, and patients with pernicious anemia. with duodenal ulcer, and patients

14 Samloff IM. Pepsinogens I and II: purification from gastric mucosa and radioimmunoassay in serum. Gastroenterology $1982 ; 82: 26-33$

15 Tatsuta $M$, Okuda $S$. Gastric ulcers in the fundic gland area Gastroenterology 1976; 71: 16-8.

16 Miyake T, Suzaki T, Oishi M. Correlation of gastric ulcer healing features by endoscopy, stereoscopic microscopy, and histology, and a reclassification of the epithelial regenerative process. Dig Dis Sci 1980; 25: 8-14.

17 Waldum HL, Straume BK, Burhol PG. Radioimmunoassay of group I pepsinogens (PG I) and the effect of food on serum PG I. Scand $\mathcal{F}$ Gastroenterol 1979; 14: 241-7.

18 Feldman M, Richardson CT, Lam SK and Samloff IM Comparison of gastric acid secretion rates and serum pepComparison of gastric acid secretion rates and serum pep-
sinogen I and II concentrations in occidental and oriental sinogen I and II concentrations in occidental and orient
duodenal ulcer patients. Gastroenterology 1988; 95: 630-5.

19 Oi M, Oshida K, Sugimura S. The location of gastric ulcer Gastroenterology 1959; 36: 45-56.

$20 \mathrm{Oi} \mathrm{M}$, Ito Y, Kumagai F, et al. A possible dual contro mechanism in the origin of peptic ulcer. Gastroenterology 1969; 57: 280-93.

21 Kimura $\mathrm{K}$. Chronological transition of the fundic-pyloric border determined by stepwise biopsy of the lesser and greater curvatures of the stomach. Gastroenterology 1972;63: greater 84 . 92 .

22 Samloff IM. Cellular localization of group I pepsinogens in human gastric mucosa by immunofluorescence. Gastroenterology 1971; 61: 185-8.

23 Johnson HD. Gastric ulcer: classification, blood group characteristics, secretion patterns and pathogenesis. Ann Surg $1965 ; 162: 996-1004$

24 Wormsley KG, Grossman MI. Maximal histalog test in control subjects and patients with peptic ulcer. Gut $1965 ; 6: 427-35$

25 Rhodes J. Etiology of gastric ulcer. Gastroenterology 1972; 63: 171-82.

26 Varis K, Isokoski M. Screening of type A gastritis. Ann Clin Res 1981; 13: 133-8.

27 Samloff IM, Stemmermann GN, Heilbrum LK, Nomura A Elevated serum pepsinogen I and II levels differ as risk factors for duodenal ulcer and gastric ulcer. Gastroenterolog 1986; 90: 570-6.

28 Sutton DR, Donaldson RM. Synthesis and secretion of protein and pepsinogen by rabbit gastric mucosa in organ culture. Gastroenterology 1975; 69: 166-74.

29 Haukland $\mathrm{HH}$, Waldum HL, Johnson JA. Effect of proxima gastric vagotomy on insulin-induced gastric $\mathrm{H}$ and pepsin
secretion and serum group I pepsinogens. Scand $\mathcal{J}$ Gastrosecretion and serum grour
enterol $1982 ; 17: 555-9$.

30 Lalla M, Paimela H, Rasanen V. Serum group I pepsinogens in unoperated duodenal ulcer patients and in duodenal ulcer patients after proximal gastric vagotomy. Scand $\mathcal{F}$ Gastro enterol 1983; 18: 397-9.

31 Paimela H, Lalla M, Rasanen V. Serum group I pepsinogen after consecutive stimulations with insulin and pentagastrin in unoperated duodenal ulcer patients and in duodenal ulce patients after proximal gastric vagotomy. Scand $\mathcal{F}$ Gastroenterol 1984; 19: 52-5.

32 Feldman M, Blair AJ, Richardson CT, Samloff IM. Effect of proximal gastric vagotomy on serum pepsinogen I and II concentrations and acid secretion in duodenal ulcer patients. Dig Dis $S c i$ 1988; 33: 824-7.

33 Battaglia G, Farini R, Di Mario F, et al. Recurrence of duodenal ulcer under continuous antisecretory treatment: an approach to the detection of predictive markers. an approach to the detection

Am f Gastroenterol 1984; 79: 831-4.
34 Waldum HL, Burhol PG, Straume BK. Serum group I pepsinogens and gastrin in relation to gastric $\mathrm{H}+$ and pepsin pepsinogens and gastrin in relation to gastric $\mathrm{H}+$ and pepsin
outputs before and after subcutaneous injection of pentagastrin. Scan $\mathcal{F}$ Gastroenterol 1978; 13: 943-6. 